\title{
Platelet Taurine Content in Friedreich's Disease
}

\author{
F. Rodrigue, F. Bélanger, N.M. van Gelder, A. Barbeau
}

\begin{abstract}
We have studied the concentrations of taurine and of 6 other amino acids in platelets from 12 patients with Friedreich's disease and 12 age sex-matched normal control subjects. No significant differences could be demonstrated between the two groups. The glycine/serine ratio was lower in all the patients but this change did not reach statistical significance. From these and other data, we conclude that the taurine retention deficit observed previously in Friedreich's disease cannot be the primary causal defect.
\end{abstract}

RÉSUMÉ: Nous avons étudié les concentrations de la taurine et de six autres acides aminés dans les plaquettes de 12 patients avec la maladie de Friedreich et de 12 témoins normaux du même âge et sexe. Nous n'avons pas mis en évidence de différence significative entre les deux groupes. Le rapport glycine/sérine était uniformément plus bas chez les patients, mais cette modification n'atteignait pas une signification statistique. Nous concluons que le déficit dans la rétention de la taurine, que nous avions préalablement mis en évidence dans la maladie de Friedreich, ne peut être causal à la maladie.

Can. J. Neurol. Sci. 1984; 11:607-609

Previous studies from our group, and from others, have shown possible defects in the handling of the amino acid taurine (2-aminoethanesulfonic acid) in Friedreich's disease. Taurine urinary excretion was found to be increased at rest in many patients (Lemieux et al., 1976; Lemieux et al., 1984, this issue). These patients do not handle a taurine load in a normal manner (Filla et al., 1979), excreting a higher proportion of the ingested load within a given time period. In this they resemble subjects with muscular dystrophy (Lemieux et al., 1984, this issue). The extent of taurine handling appears to follow a genetic pattern (Barbeau et al., 1982), as described in other entities and normal control subjects by Goodman et al. (1980). The concentration of taurine in the cerebrospinal fluid is normal (Lemieux et al., 1978), but it is slightly elevated in the cerebellum (Huxtable et al., 1979) in Friedreich's disease. Studies on the uptake of taurine in platelets (Filla et al., 1978) and in fibroblasts (Melançon et al., 1979, 1980) were essentially normal in this disease.

Despite the above studies, no data is available on tissue concentrations in Friedreich's disease patients in vivo. We therefore decided to study this aspect in platelets of patients with this disorder, since it is known that platelets are normally rich in taurine (Fredo et al., 1959).

\section{SubJeCtS AND MethodS}

Platelets were obtained from 12 patients responding to the typical criteria for Friedreich's disease as previously defined
(Geoffroy et al., 1976) and from age-matched normal (non neurological) controls. The mean age of the patients was 28.75 years, that of the controls 28.66 years. In each group there were 7 women and 5 men.

Blood was collected by venipuncture at $9: 00 \mathrm{a} . \mathrm{m}$. from fasting ( $8-12 \mathrm{hrs}$ ) subjects in $20 \mathrm{ml}$ plastic syringes, each containing $1.5 \mathrm{ml}$ sodium ethyllenediaminetetracetic acid (EDTA) solution with $0.016 \mathrm{mg}$ potassium sorbate. Blood was transferred immediately to centrifuge tubes and cooled in ice. Each patient was matched with a control subject done the same day. Tubes were centrifuged $\left(100 \mathrm{~g}, 15\right.$ minutes, $\left.4^{\circ} \mathrm{C}\right)$ to obtain platelet rich plasma (PRP). All manipulations were performed with silicone pipettes and tubes. Platelet count was done microscopically from the platelet rich plasma. Four counts were performed on each platelet rich sample according to the Rees-Ecker method (BDH formaldehyde solution $35 \%, 0.2 \mathrm{ml}$; sodium citrate, 3.8 $\mathrm{gm}$; brilliant cresyl blue, $0.05 \mathrm{~g}$; tri-distilled water, $100 \mathrm{ml}$ ), and the mean value per $\mathrm{mm}^{3}$ used for calculation.

A $5 \mathrm{ml}$ aliquot of platelet enriched plasma was centrifuged at $2,000 \times \mathrm{g}$ for $20 \mathrm{~min}$. This procedure was repeated after resuspension of the pellet in $5 \mathrm{ml}$. Gey's Balanced Salt Solution (GIBCO) [milimolar: $\mathrm{CaCl}_{2}, 1.5 ; \mathrm{KCl}, 3.30 ; \mathrm{KH}_{2} \mathrm{PO}_{4}, 0.27$; $\mathrm{MgCl}_{2} .6 \mathrm{H}_{2} 0,1.89 ; \mathrm{MgSO}_{4} .7 \mathrm{H}_{2} 0,0.63 ; \mathrm{NaCl}, 60 ; \mathrm{NaHCO}_{3}, 27$; D-glucose, 9; pH 8.0] containing 5 mM EDTA- $\mathrm{Na}_{2}$; no platelet lysis occurs under these circumstances. Another $5 \mathrm{ml}$ aliquot, treated separately, but in identical manner, served for protein determination. This pellet was subjected to three cycles of

From the Clinical Research Institute of Montreal and the Université de Montréal.

Reprint requests for the complete supplement on Friedreich's disease (Phase 3, Part 3) to: Prof. André Barbeau, Clinical Research Institute of Montreal, 110 Pine Avenue West, Montreal, Quebec, Canada H2W 1R7. 
freeze-thawing in $1 \mathrm{ml}$ water to lyse the cells, diluted to $5 \mathrm{ml}$ with $\mathrm{H}_{\mathbf{2}} \mathbf{0}$, and subjected to protein determination by the Lowry method (Lowry et al., 1951).

To release free amino acids, the other washed pellet was weighed, suspended in approximately $0.7 \mathrm{ml}$ of $\mathrm{H}_{2} 0$, placed in a boiling water bath for $20 \mathrm{~min}$., and homogenized. Before volumetric completion of the suspension to give a final tissue concentration of $20 \mathrm{mg} / \mathrm{ml}$, ten times concentrated amino acid analytical lithium buffer (Pierce) was added to the cooled solution, so that upon completion to final volume the solution was $0.2 \mathrm{~N}$, $\mathrm{pH} 2.0$. This was centrifuged $(20,000 \mathrm{xg}, 1 \mathrm{hr}$.), passed through a $2.2 \mu$ Milipore filter, and the filtrate stored frozen until amino acid analysis. Amino acid levels are expressed per mg protein or per $10^{10}$ platelets, after calculation of the number of platelets $/ \mathrm{mg}$ protein (platelets $/ 5 \mathrm{ml}$ ) and $\mathrm{mg}$ protein $/ 5 \mathrm{ml}$ enriched plasma.

The equipment used for amino acid determinations consisted of two Beckman programmable HPLC pumps to generate a gradual $\mathrm{pH}$ gradient over a period of 30 min., using Pierce Type A lithium buffer $0.15 \mathrm{~N}, \mathrm{pH} 2.5$ and lithium hydroxide $0.2 \mathrm{~N}$. The $4 \mathrm{~mm} \times 15 \mathrm{~cm}$ stainless steel column was packed with Beckman $3 \mathrm{H}-\mathrm{W}$ resin, heated to $50^{\circ} \mathrm{C}$. Post-column ninhydrin derivatization was employed to obtain the amino acid elution spectrum, using a modified spectrophotometer flow-through cell, at a wavelength of 570 nmeter. Maximum sensitivity was 0.5 nmoles, with a reproducibility for the same sample of $3-5 \%$.

\section{RESULTS}

Platelets counts were identical in both groups of subjects (Table 1). The concentrations of the various amino acids are given in Table 2. The values for taurine are of the same order of

\begin{tabular}{llc}
\hline \multicolumn{2}{l}{ Table 1: Platelet Counts } \\
\hline \hline & $\mathbf{N}$ & Platelets/mI PRP x 10 $\mathbf{1 0}^{\mathbf{8}} \mathbf{\text { SD }}$ \\
\hline Friedreich & 12 & $4.21 \pm 1.39$ \\
Normal controls & 12 & $4.35 \pm 1.05$ \\
\hline
\end{tabular}

Table 3: Amino-Acid Ratios in Platelets ( $\mu$ Mole/g Prot. $/ \mu$ Mole/g Prot.)

\begin{tabular}{lcc}
\hline \hline RATIOS & $\begin{array}{c}\text { NORMAL CONTROLS } \\
(\mathbf{N}=\mathbf{1 2})\end{array}$ & $\begin{array}{c}\text { FRIEDREICH } \\
(\mathbf{N}=\mathbf{1 2})\end{array}$ \\
\hline TAU/GLU & $11.93 \pm 2.78$ & $11.41 \pm 5.25$ \\
TAU/GLM & $54.23 \pm 31.32$ & $32.39 \pm 11.61$ \\
GLY/SER & $3.15 \pm 1.59$ & $2.35 \pm 1.30$ \\
TAU/GLY & $61.05 \pm 34.52$ & $57.20 \pm 13.40$ \\
GLY/THR & $2.99 \pm 2.27$ & $2.45 \pm 1.16$ \\
GLU/GLM & $3.78 \pm 1.10$ & $2.86 \pm 0.94$ \\
\hline
\end{tabular}

magnitude as those reported by Paasonen et al. (1980). All other amino acid levels in platelets also appear normal in Friedreich's disease, with possibly a slight tendency towards lower glycine and slightly higher serine concentrations, giving rise to a somewhat lower GLY/SER ratio. Other ratios in Friedreich's disease were even closer to those found in platelets of control subjects (Table 3).

\section{Discussion}

Platelets are known to contain very large amounts of taurine in comparison to the content of any of the other amino acids (Fredo, 1959; Paasonen, 1980). Our results confirm these findings. Despite our earlier suggestion (Filla et al., 1978) that, in Friedreich's disease, taurine is lost more easily from sites of retention, our study suggests that the platelet taurine levels in patients with that disorder are entirely normal. These results are in keeping with the normal transport system for Beta-amino acids previously demonstrated (Filla et al., 1978; Melançon et al., 1979, 1980) in such patients, but do not explain the higher urinary excretion of taurine observed in some Friedreich cases (Lemieux et al., 1978). The relative concentration of the various other amino acids does not appear to suffer major changes in Friedreich's disease, except for the trend towards a lower glycine/serine ratio. This is compatible with the significantly lower plasma glycine concentrations found previously in Friedreich's disease (Lemieux et al., 1976). The significant decrease in the glutamate/glutamine ratio in the brain of Friedreich's patients found by Huxtable et al., 1984 (this issue), was not apparent in platelets.

The sum total of these and previous findings does not indicate that a defect of taurine tissue retention plays a major etiologic role in Friedreich's disease.

Friedreich's patients, like any other subject suffering from metabolic or physical stresses to the heart, muscles and brain, require taurine to maintain osmotic homeostatism (van Gelder, 1983) and possibly to decrease the severity of the heart and other lesions caused by ionic changes (Azari et al., 1980). When these stresses occur, larger quantities of taurine are probably needed immediately. Freidreich's patients can take up taurine normally and their plasma concentrations reach normal levels at the normal time (Filla et al., 1979). This excess taurine reaches the urine more rapidly than in control subjects (Barbeau et al., 1982). The reason for this behavior is still unknown, but is probably related to a diminished muscle mass (see Lemieux et al., 1984, this issue). Whether this defect is influenced by the decreased concentrations of linoleic acid in the membranes

Table 2: Amino-Acid Concentrations in Platelets

\begin{tabular}{|c|c|c|c|c|}
\hline \multirow[b]{2}{*}{ Amino-Acid } & \multicolumn{2}{|c|}{ NORMAL CONTROLS $(N=12)$} & \multicolumn{2}{|c|}{ FRIEDREICH'S DISEASE $(\mathbf{N}=12)$} \\
\hline & $\mu$ Mole/g Prot. & $\mu$ Mole $/ 10^{10}$ Platelets & $\mu$ Mole/g Prot. & $\mu$ Mole $/ 10^{10}$ Platelets \\
\hline Taurine (TAU) & $239.8 \pm 62.0$ & $3.83 \pm 0.70$ & $217.3 \pm 64.8$ & $3.73 \pm 0.87$ \\
\hline Glutamate (GLU) & $21.2 \pm 8.1$ & $0.34 \pm 0.08$ & $20.9 \pm 6.7$ & $0.37 \pm 0.14$ \\
\hline Glutamine (GLM) & $5.6 \pm 2.6$ & $0.10 \pm 0.06$ & $7.3 \pm 3.0$ & $0.13 \pm 0.07$ \\
\hline Aspartate & $11.8 \pm 5.3$ & $0.19 \pm 0.06$ & $14.3 \pm 5.4$ & $0.25 \pm 0.10$ \\
\hline
\end{tabular}


(Huang et al., 1980; Yorek et al., 1984), by genetics (Goodman et al., 1980) or by a deficit in pantothenic acid which is known to increase taurine excretion (Koyanagi and Obori, 1965) or by all these changes, is still to be decided by further studies. The end result, however, is that Friedreich's disease patient may not have available, at the proper place and at the proper time, the quantity of extra taurine required to dampen the metabolic and osmotic effects of these stresses, despite the fact that tissue taurine concentrations (at metabolic rest) are normal.

\section{ACKNOWLEDGEMENT}

The studies reported in this paper were made possible through a grant from "L'Association Canadienne de l'Ataxie de Friedreich". The authors would like to thank Miss Suzanne Paris, RN, for the clinical studies and blood sampling procedures and Mrs. Nicole GuayPoirier for typing the manuscript.

\section{REFERENCES}

Azari J, Brumbauch P, Barbeau A, Huxtable R(1980) Taurine decreases lesion severity in the heart of cardiomyopathic hamsters. Can J Neurol Sci 7: 435-440.

Barbeau A (1982) Friedreich's disease 1982: Etiologic hypothese - A personal analysis. Can J Neurol Sci 9: 243-263.

Barbeau A, Patenaude F, Nadon G, Charbonneau M, Cloutier T (1982) A possible genetic pattern of taurine urinary excretion in Friedreich's ataxia. Can J Neurol Sci 9: 209-215.

Filla A, Butterworth RF, Barbeau A (1979) Pilot studies on membranes and some transport mechanism in Friedreich's ataxia. Can J Neurol Sci 6: 285-289.

Filla A, Butterworth RF, Geoffroy G, Lemieux B, Barbeau A (1978) Platelet taurine uptake in spino-cerebellar degeneration. Can J Neurol Sci 5: 119-123.

Fredo J, Koj A, Zgliczynski JM (1959) Taurine in human blood platelets. Nature 183: 685-686.
Geoffroy G, Barbeau A, Breton G, Lemieux B, Aubé M, Léger C, Bouchard JP (1976). Clinical description and roentgenologic evaluation of patients with Friedreich's ataxia. Can J Neurol Sci 3: 279-286.

Goodman HD, Connolly BM, McLean W, Resnick M (1980) Taurine transport in epilepsy. Clin Chem 26: 414-419.

Huang YS, Marcel YL, Vezina C, Barbeau A, Davignon J (1980) Lecithin: cholesterol acyltransferase activity and fatty acid composition of erythrocyte phospholipids in Friedreich's ataxia. Can J Neurol Sci 7: 429-434.

Huxtable R, Azari J, Reisine T, Johnson P, Yamamura $H$ and Barbeau A (1979) Regional distribution of amino acids in Friedreich's ataxia brains. Can J Neurol Sci 6: 255-258.

Koyanagi T, Obori H (1965) Effect of pantothenic acid and vitamin $B_{6}$ on the excretion of taurine in the urine of rats. Tohoku J Exp Med 86: 394-396.

Lemieux B, Barbeau A, Beroniade V, Shapcott D, Breton G, Geoffroy G, Melançon S (1976) Amino acid metabolism in Friedreich's ataxia. Can J Neurol Sci 3: 373-378.

Lemieux B, Giguère R, Barbeau A, Melançon S, Shapcott D (1978) Taurine in cerebrospinal fluid in Friedreich's ataxia. Can J Neurol Sci 5: 125-129.

Lowry OH, Rosenbrough NJ, Farr AL, Randall RJ (1951) Protein measurement with the folin phenol reagent. Meth Enzymol 3: 447-454.

Melançon SB, Grignon B, Ledru E, Geoffroy G, Potier M. Dallaire L. Vanasse M(1980) The Beta-amino acid transport system in Friedreich's ataxia. Can J Neurol Sci 7: 441-446.

Melançon SB, Grignon B, Potier M, Dallaire L (1979) Taurine and Beta-alanine uptake in cultured human skin fibroblasts from patients with Friedreich's ataxia. Can J Neurol Sci 6: 251-253.

Paasonen MK, Penttilä O, Hiniberg JJ, Solatunturi E (1980) Platelet taurine in patients with arterial hypertension, myocardial failure or infarction. Acta Med Scand (supp). 642: 79-84.

van Gelder NM (1983) Principles of Compartmentation. In: Lajtha A (ed.). Handbook of Neurochemistry, Plenum Publishing Corp., vol. 2 (2nd edition), pp 183-206.

Yorek MA, Strom DK, Spector AA (1984) Effect of membrane polyunsaturation on carrier-mediated transport in cultured retinoblastoma cells: alterations in taurine uptake. J Neurochemistry 42 : 254-261. 